\title{
Trace element contamination in the mine-affected stream sediments of Oued Rarai in north-western Tunisia: a river basin scale assessment
}

\author{
Jamel Ayari • Maurizio Barbieri (D) - Yannick Agnan • Ahmed Sellami • \\ Ahmed Braham - Faouzi Dhaha $\cdot$ Abdelkarim Charef
}

Received: 25 August 2020/ Accepted: 12 March 2021 / Published online: 26 March 2021

(C) The Author(s) 2021

\begin{abstract}
High-quality and accurate environmental investigations are essential for the evaluation of contamination and subsequent decision-making processes. A combination of environmental geochemical indices, multivariate analyses and geographic information system approach was successfully used to assess contamination status and source apportionment of trace elements $(\mathrm{Ag}, \mathrm{As}, \mathrm{Cd}, \mathrm{Cr}, \mathrm{Cu}, \mathrm{Hg}, \mathrm{Ni}, \mathrm{Pb}, \mathrm{Sb}$, $\mathrm{V}$ and $\mathrm{Zn}$ ) in surface stream sediments from the Oued Rarai basin in north-western Tunisia, containing various metal and metalloid ores. The contamination level reported in this study indicates a non-negligible potential ecological risk, mainly related to sediment
\end{abstract}

Supplementary Information The online version contains supplementary material available at https://doi.org/10.1007/ s10653-021-00887-1.

J. Ayari · A. Sellami · A. Braham · F. Dhaha

National Office of Mines, 24 rue 8601 La Charguia,

1080 Tunis Cedex, Tunisia

M. Barbieri $(\bowtie)$

Dip. Scienze Della Terra, Università Di Roma "La Sapienza", P.Le Aldo Moro, 5-00185 Roma, Italy e-mail: Maurizio.barbieri@uniroma1.it

\section{Y. Agnan}

Earth and Life Institute, Université Catholique de Louvain, 1348 Louvain-la-Neuve, Belgium

\section{A. Charef}

Université de Carthage, Sidi Bou Said, Avenue de La République, 1054 Tunis Cedex, Tunisia transport along the river. Antimony (concentrations ranged from 0.02 to $297 \mathrm{mg} \mathrm{kg}^{-1}$ and Igeo $>5$ ), arsenic (from 0.5 to $1490 \mathrm{mg} \mathrm{kg}^{-1}$ and Igeo $>5$ ), lead (from 2.9 to $5150 \mathrm{mg} \mathrm{kg}^{-1}$ and Igeo $>5$ ) mercury (from 0.05 to $54.4 \mathrm{mg} \mathrm{kg}^{-1}$ and Igeo $>5$ ) and silver (from 0.05 to $9.4 \mathrm{mg} \mathrm{kg}^{-1}$ and Igeo $>5$ ) showed the most crucial contamination. Besides, potential ecological risk index values were maximum for arsenic with a median of 302, indicating a very high to serious ecological risk ( $>160$ ). Results from correlation analysis and principal component analysis revealed three main geochemical associations related to lithologic, tectonic and anthropogenic sources. V, $\mathrm{Cr}$ and $\mathrm{Cu}$ mainly originated from natural bedrock and soil. Ag and $\mathrm{Cd}$ were more controlled by both natural and mining enrichments. Mercury and $\mathrm{Pb}$ were mostly influenced by the ancient ore-related activities at the Oued Rarai site and north-east-south-west trending faults. Finally, $\mathrm{Sb}, \mathrm{As}, \mathrm{Ni}$ and $\mathrm{Zn}$ were largely controlled by the siliciclastic continental Neogene sequences. Finally, the physical and chemical dynamics of the watershed system, lithological properties, mineralisation, tectonic settings and mobilisation of subsurface sediments largely controlled both concentrations and spatial patterns of trace elements in the study basin. These results need to be considered in the strategies of suitable environmental management at former and current mining sites in north-western Tunisia. 
Keywords Trace elements - Contamination · Source $\cdot$ Spatial distribution $\cdot$ Stream sediments $\cdot$ Oued Rarai basin

\section{Introduction}

Historical metal mining districts have been generating significant quantities of mining wastes, which have been routinely discharged into the river systems (Clement et al., 2017; Li et al., 2019; Macklin et al., 2006; Nguyen et al., 2020; Salomons, 1995). Many studies have shown that nearly $90 \%$ of trace metal contaminants in a river system are usually associated with sediments (Argyraki et al., 2018; HudsonEdwards et al., 2001; Hudson-Edwards et al., 2001; Meybeck \& Helmer, 1989; Nguyen et al., 2020), and between 10 and $60 \%$ of the sediments discharged into the river systems can be deposited and stored within the river channels and on the floodplains bordering the channels (Goodbred \& Kuehl, 1998; Owens et al., 1997).

Nowadays, contaminated sediments from river channels and floodplains continue to be a potential secondary source for trace element contamination in the hydrographic systems (Axtmann \& Luoma, 1991; Clement et al., 2017). The contaminated sediments stored on floodplains can be remobilised and returned to the water-sediment interface, particularly during high-flow conditions (Lecce \& Pavlowsky, 1997; Matys Grygar et al., 2014). The accumulation of trace elements in alluvial soils and sediments can have adverse effects on human livelihoods and sustainable development.

In northern Tunisia, mining of $\mathrm{Pb}-\mathrm{Zn}$ ore deposits and associated activities have resulted in the discharge of important quantities of mining wastes into the fluvial systems (e.g. Jemmali et al., 2013; Sainfeld, 1952; Slim-Shimi \& Tlig, 1993). Environmental studies on the impacts of these former mining activities have been conducted on the transfer and mobility of trace elements in mining wastes, soils and sediments (e.g. Souissi et al., 2013; Daldoul et al., 2015; Pascaud et al., 2015). In general, the retention capacity of soil for trace elements increases in tandem with an increasing $\mathrm{pH}$, with the expected maximum being around circumneutral. Exceptions are As, Mo, $\mathrm{Se}, \mathrm{V}$ and $\mathrm{Cr}$, which are commonly more mobile under alkaline conditions (Sbarbati et al., 2020; Sappa et. al., 2019; Violante et al., 2010). Neutral pH and the high carbonate content play an important role in trace elements stability, in such a way that there is no transfer of soluble trace elements, the elements beings only mobilised in particulate form (Boussen et al., 2013; Pascaud et al., 2015).

Matys Grygar and Popelka (2016) reported that the settling of particles from flowing water (i.e. the distribution of solid particles between suspended load and bedload) and the variable lithology of deposits in individual fluvial environments are the primary factors driving the variability of risk-element concentrations in fluvial sediments. Finally, the biogeochemical processes can modify the sediment composition during weathering, pedogenesis and further transformations of the finest particles transported by the river in the aftermath of flooding events (Luis et al., 2019; Matys Grygar \& Popelka, 2016).

Previous studies (e.g. Mlayah et al., 2009; Ayari et al., 2016) in another abandoned $\mathrm{Pb}-\mathrm{Zn}$ mining site in northern Tunisia (80-100 km far from this studied site) highlight the elevated concentrations of potentially toxic trace elements released in the nearest watercourses of the past mining and metallurgical (As, $\mathrm{Cd}, \mathrm{Pb}$ and $\mathrm{Zn})$ as well as agricultural activities $(\mathrm{Cu}$ and As).

In Tunisia, the Mejerda basin is one of the most important agricultural sectors (Guellala et al., 2012). It has a strong need for irrigation water. During rainy periods, Oued Mejerda River and its tributaries are the primary sources to irrigate the vegetation (Guellala et al., 2012).

No geochemical data are published on the Oued Rarai basin (Figs. 1,2) that occupies the western area of the Medjerda river.

For that reason, the objectives of this study are:

- to assess the spatial distribution, enrichment and source apportionment of trace elements (antimony, arsenic, cadmium, chromium, copper, lead, mercury, nickel, silver, vanadium and zinc) in stream sediments from the Oued Rarai basin;

- to provide a reference for the systematic evaluation and remediation of soil contamination and sustainable management of land in the unique habitat of northern Tunisia;

- to improve the proper consideration of the transfer of trace elements under large flooding events 


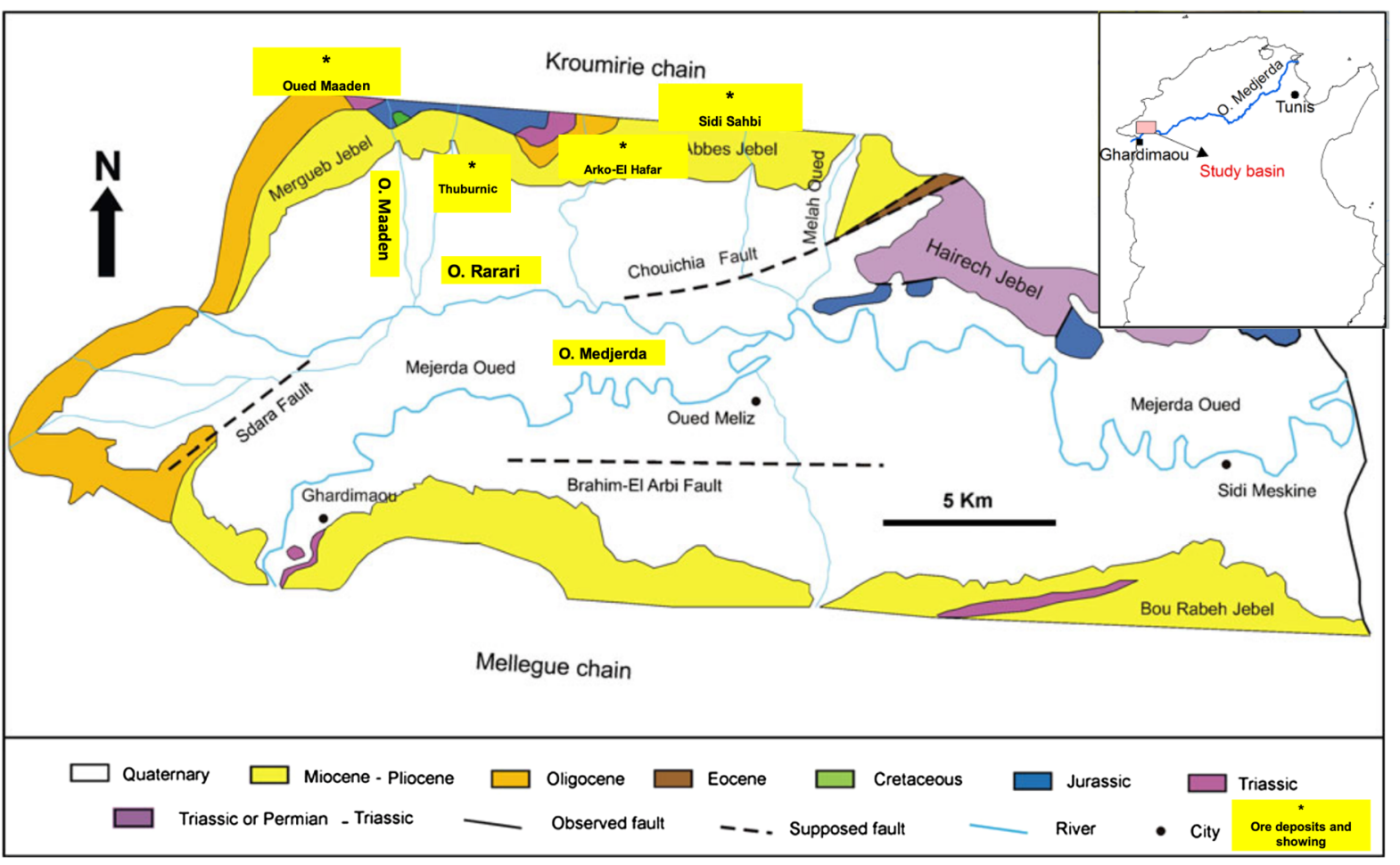

Fig. 1 Geological and metallogenic maps of the study basin ( modified from Guellala et al., 2012)

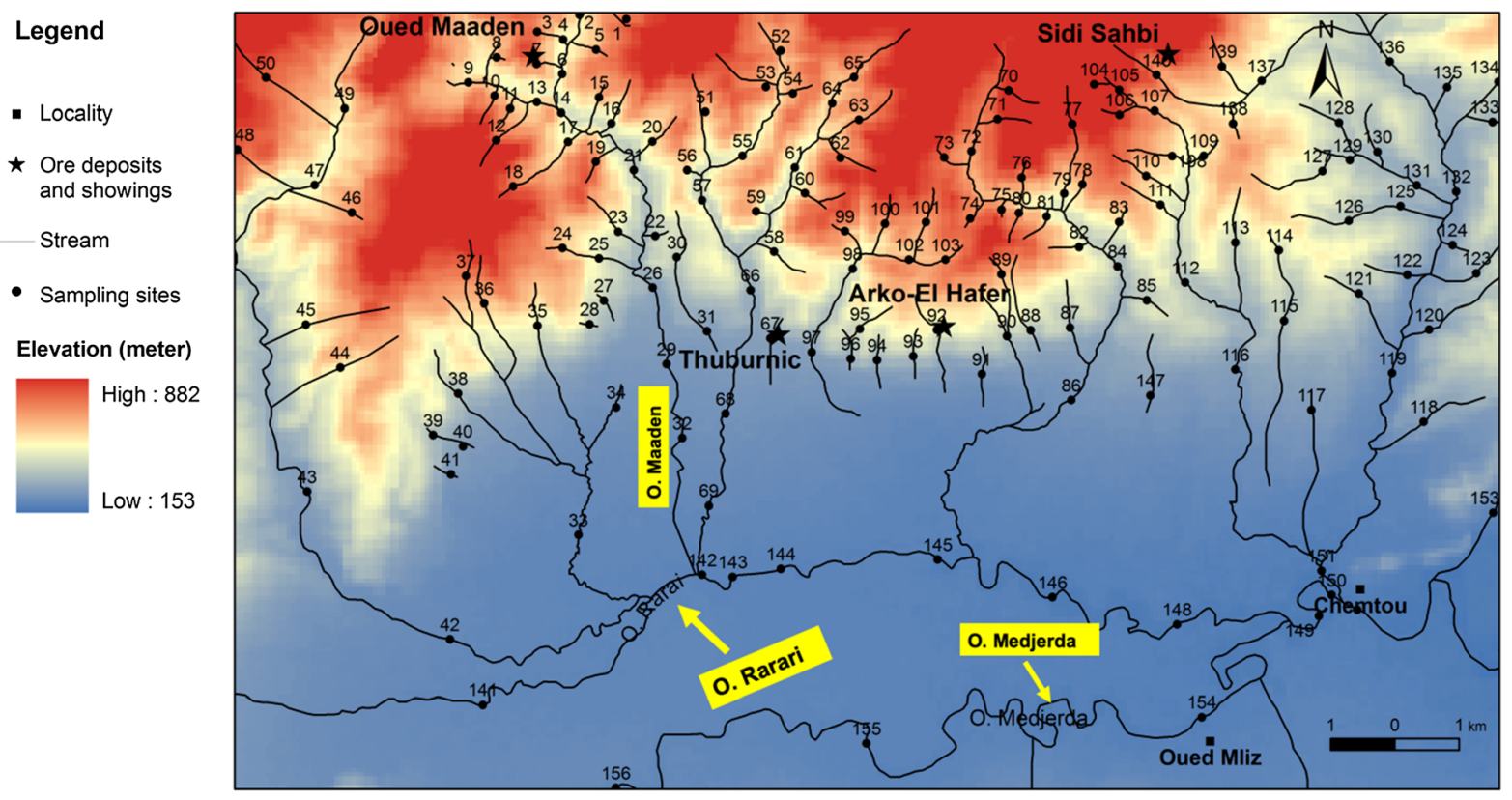

Fig. 2 Location of the sampling sites in the study basin

similar to those of the Mediterranean region in recent years (Gaume et al., 2009; Llassat et al., 2010);
As guidelines, in this study, we use Dutch soil intervention values. The Intervention values for soil indicate when the functional properties of the soil for 
humans, plants and animals are seriously impaired or in danger of being so. Contamination of soil above the Intervention values is deemed to be severe. The soil Intervention Values apply to dry soil. The soil intervention values were first published in 2000, some of the values have been adjusted since then (Ana Payá Pérez, Natalia Rodríguez Eugenio, 2018-Status of local soil contamination in Europe, Revision of the indicator 'Progress in the management contaminated sites in Europe'; European Commission, JRC Technical Reports, https://esdac.jrc.ec.europa.eu/public_ path/shared_folder/doc_pub/EUR29124.pdf).

Dutch policy concerning contaminated land has evolved over more than three decades from a rigid assessment procedure, partly based on expert judgement, to a more flexible and tiered fitness-for-use approach with risk assessment as the underlying principle. The process to assess and appraise soil and groundwater quality follow a tiered approach, under the principle 'simple if possible, complex when necessary'. The web-based decision support system Sanscrit has been designed to support the risk assessments within the respective policy contexts, which combine the scientific aspects of risk assessment with policy choices for protection targets and protection levels (Ana Payá Pérez, Natalia Rodríguez Eugenio, 2018-Status of local soil contamination in Europe, Revision of the indicator 'Progress in the management contaminated sites in Europe'; European Commission, JRC Technical Reports, https://esdac.jrc.ec.europa.eu/ public_path/shared_folder/doc_pub/EUR29124.pdf

\section{Materials and methods}

Study area

The Oued Rarai basin occupies the western area of the Medjerda River, close to the Algerian-Tunisian border, and covers nearly $467 \mathrm{~km}^{2}$ (Fig. 1). According to the 1992-2002 meteorological data (INM, 2003), the local climate is sub-humid, with the average annual rainfall ranging from 600 to $800 \mathrm{~mm}$ occurring mostly during winter and autumn as heavy storms. The average annual temperature oscillates between $14.5{ }^{\circ} \mathrm{C}$ and $18.2{ }^{\circ} \mathrm{C}$. Similar to the Mediterranean region, the frequency of large flooding events resulting in large inundations of the floodplain has increased in recent years (Gaume et al., 2009; Llassat et al., 2010).
Morphologically, the northern part of the Oued Rarai basin comprises the north-east-south-west (NESW) Kroumirie chain (Tell region) and the southern part of the Ghardimaou plain, which is drained by Oued Rarai and Oued Medjerda (Fig. 2). The Kroumirie chain, part of the Nappe zone, consists of a pile of allochthonous thrust sheets formed during the Neogene tectonic event (Rouvier, 1977) with felsic plugs and mafic dikes, sills and basaltic flows of the late Miocene and Pliocene Nefza magmatic province (Jallouli et al., 2003).

The main lithologies exposed in the study basin include carbonate and siliciclastic sedimentary series ranging from the Triassic to the recent age (Fig. 1): Triassic gypsum, clays, dolostones and limestones, Jurassic dolomites, Cretaceous clay and limestone, Oligocene siliciclastic flysch (Numidian flysch), continental Neogene siliciclastic sediments and Quaternary and recent fluvial deposits in the plain.

The study basin contains several $\mathrm{Pb}-\mathrm{Zn}$ ore deposits, $\mathrm{Hg}$ mine, including Oued Maaden, Thuburnic and Arko El Hafer (Fig. 1; Decrée et al., 2013; Jemmali et al., 2013; Sainfeld, 1952; Slim-Shimi \& Tlig, 1993). According to Rouvier et al. (1985), two distinct types of $\mathrm{Pb}-\mathrm{Zn}$ deposits can be found. The first $\mathrm{Pb}-\mathrm{Zn}$ mineralisation includes the enrichment of $\mathrm{As}$ and $\mathrm{Sb}$ and occurs in the continental Neogene sequences. The second one shows the enrichment of As and $\mathrm{Hg}$ and is found in fractures locally injected with Neogene volcanic rocks. The Oued Maaden mine constitutes the most economic ore deposits of the study basin. Mineralisation is found at Oued Maaden along the NE-SW Groura and Ferza trending faults developed within the Triassic dolostone and the Campanian-Maastrichtian limestone rocks (Jemmali et al., 2013). The main ore minerals are galena, sphalerite, tetrahedrite, malachite, cinnabar and AsSb-rich sulfosalts alongside other elements, such as Ag and Cd (Jemmali et al., 2013; Sainfeld, 1952; SlimShimi \& Tlig, 1993). These minerals commonly occur along the main vein and stockwork systems. The Oued Maaden mine was extensively exploited from 1900 to 1955 and produced over 11,500 tons of $\mathrm{Pb}$ and 89 tons of $\mathrm{Cu}$ concentrates with an $\mathrm{Ag}$ concentration of $350 \mathrm{mg} \mathrm{kg}^{-1}$ (Sainfeld, 1952). Finally, in the southwest part of the study area is localised the Ghardimaou plain that is one of the most fertile soils in Tunisia, used for intensive agriculture mostly consisting of cereals, vegetables, orchards and fodder crops. 
Sample collection and analytical procedure

A stainless-steel shovel and a tube auger were used to collect 156 stream sediment samples $(1-1.5 \mathrm{~kg}$ of active sediment) from the Oued Rarai basin (Fig. 2) in March 2016. The samples were subsequently stored in polyethylene bags. For each site, three to five subsamples were collected at the upper 5-cm sediment in a maximum range of $200 \mathrm{~m}$ (Salminen et al., 1998) and then pooled together to obtain a homogeneous composite sample. Geographic coordinates of each sampling site were recorded on a field sheet.

In the laboratory, sediment $\mathrm{pH}$ was measured in a 1:5 sediment-water suspension using a METTLER TOLEDO pH Electrode (LE427-IP67).

Bulk sediment samples were air-dried, sieved to $2 \mathrm{~mm}$ with a stainless-steel sieve and manually crushed in an agate mortar. Sub-sample $(0.5 \mathrm{~g})$ was heated in a mixture of $5 \mathrm{~mL}$ of $\mathrm{HNO}_{3}, 10 \mathrm{~mL}$ of $\mathrm{HClO}_{4}$ and $10 \mathrm{~mL}$ of $\mathrm{HF}$ to fuming and taken to dryness (Khalil et al., 2013).

Total concentrations of $\mathrm{Ag}, \mathrm{As}, \mathrm{Cd}, \mathrm{Co}, \mathrm{Cr}, \mathrm{Cu}, \mathrm{Hg}$, $\mathrm{Ni}, \mathrm{Pb}, \mathrm{Sb}, \mathrm{V}$ and $\mathrm{Zn}$ were determined using inductively coupled plasma-atomic emission spectroscopy (Ultima C HORIBA-Jobin Yvon) at the National Office of Mines in Tunis, Tunisia. The quality of the analytical procedure for the total trace element concentrations was checked by analysing the stream sediment reference samples (from National Office of Mines, Tunisia) and eight replicate samples for which the relative standard deviations (\%RSDs) were less than $10 \%$ for the trace elements. According to the trace element, the recovery $\left(\right.$ Concetration $_{\text {measured }} /$ Concentration $_{\text {certified }} \times 100$ ) was in the range of $84-112 \%$ (supplementary file S1).

Geochemical background and environmental indices

\section{Geochemical background}

The geochemical background is considered to be an element or compound concentration unaffected by anthropogenic inputs (Baize \& Sterckeman, 2001). The threshold value is defined as an upper limit without an anthropogenic influence (Matschullat et al., 2000; Taylor \& Kesterton 2002; Reimann \& Garrett, 2005).
In this study, the geochemical background thresholds were determined using a multi-element geochemical data set of Ghardimaou topographic map of scale 1:50.000 collected during a regional geochemical survey by the Tunisian National Office of Mines (Loukil, 1994). For the survey a total of 1090 samples with a sample density of 1-2 samples per $\mathrm{km}^{2}$ were analysed for trace elements using the same analytical procedures previously discussed. The average per cent recovery was between 86 and $108 \%$ for all the investigated trace elements. The distribution function method was used to estimate the geochemical background distributions due to its robustness (Matschullat et al., 2000). This statistical procedure is based on the assumption that the first part of the data set (i.e. from the minimal value to the median value) is not influenced by anthropogenic inputs. In this study, the second half of the distribution was built by 'mirroring' each value against the median by adding the distance from the value to the median. The mean and standard deviation $(\sigma)$ scores of the newly obtained data set were used to calculate the geochemical background threshold: mean $+2 \sigma$ (Matschullat et al., 2000). In the proposed case study, not only the data set from minimal to median value, but also the data set from median to maximum value would be considered as data set that is also not influenced by anthropogenic activities.

\section{Geoaccumulation index}

The geoaccumulation index (Igeo) was used to evaluate the level of trace element contamination in sediments. The Igeo was originally defined by Müller (1979) and widely used in environmental studies (Barbieri et al., 2014, 2018; Wang et al., 2014). This index was calculated for each trace element as follows:

Igeo $=\log _{2}\left(\frac{C_{x}}{1.5 B_{x}}\right)$

where $C_{x}$ is the measured metal concentration; $B_{x}$ is the geochemical background value of the element of concern using the upper continental crust (UCC; Taylor \& McLennan, 1985); and the constant 1.5 is the geochemical background matrix correction factor used to minimise possible variations in the background values due to natural sources. Igeo was classified into seven classes of contamination level 
(supplementary file S2), as described by Müller (1979).

\section{Potential ecological risk index}

To assess the ecological risk of trace elements in analysed sediments, the potential ecological risk index (RI), originally introduced by Hakanson (1980), was calculated using the sum of risk factors of individual trace elements. This index was calculated as follows:

$\mathrm{RI}=\sum_{\mathrm{i}=1}^{\mathrm{n}} \mathrm{E}_{\mathrm{i}}$

where $E_{i}$ is the potential ecological risk factor for each trace element $i$ defined as:

$\mathrm{E}_{\mathrm{i}}=\mathrm{T}_{\mathrm{i}} \frac{\mathrm{C}_{\mathrm{i}}}{\mathrm{B}_{\mathrm{i}}}$

where $T_{i}$ is the toxic-response factor for each trace element I, as calculated by Hakanson (1980) (i.e. $\mathrm{Hg}=40, \mathrm{Cd}=30, \mathrm{As}=10, \mathrm{~Pb}=\mathrm{Cu}=\mathrm{Ni}=\mathrm{Co}=5$, $\mathrm{Cr}=\mathrm{V}=2$, and $\mathrm{Zn}=1 ; \mathrm{C}_{\mathrm{i}}$ is the measured concentration of the trace element $\mathrm{i} ; \mathrm{B}_{\mathrm{i}}$ is the background value of the trace element $\mathrm{i}$ using UCC data set (Taylor \& McLennan, 1985; Wedepohl, 1995). Hakanson (1980) defined four levels of RI and five levels of $\mathrm{E}_{i}$ (supplementary file $\mathrm{S} 2$ ).

Source identification and apportion contributions

Principal component analysis (PCA), a common traditional multivariate statistical tool, was used to classify different groups of trace elements in stream sediments regarding their geochemical patterns (Chen et al., 2016; Varol, 2011). Recently, many approaches have been proposed to identify contamination sources and apportion contributions of each identified source (Ribeiro et al., 2010; Wang et al., 2014).

Data analysis

All descriptive statistics were performed using SPSS 20 (IBM Corp., Armonk, NY). Multivariate analyses were performed with R 3.5.1 (R Foundation for Statistical Computing, Vienna). FactoMineR and factoextra packages were used to perform the PCA.

\section{Results and discussion}

Stream sediment $\mathrm{pH}$

The solubility of trace elements highly depends on the $\mathrm{pH}$ values of sediment: it generally tends to increase at lower $\mathrm{pH}$ and decrease at higher $\mathrm{pH}$ (Rieuwerts et al., 2015; Wang et al., 2015). In this study, the $\mathrm{pH}$ values of sediment samples ranged from 7.4 to 8.5 , with a mean value of 8.1 , which implies moderately alkaline conditions for sediment samples. These results are in agreement with data from northern Tunisia (Boussen et al., 2013; Pascaud et al., 2015).

Based on the $p$ values and Pearson correlation (Table 1), sediment $\mathrm{pH}$ did not correlate with the trace element concentrations. Due to the moderately alkaline environment, $\mathrm{pH}$ has a limited impact on the distributions of trace elements in stream sediments, substantially limiting their mobility (Boussen et al., 2013; Pascaud et al., 2015).

Trace element concentrations and contamination levels

\section{Antimony}

Antimony concentrations ranged from 0.02 to $297 \mathrm{mg} \mathrm{kg}^{-1}$ (Table 2). In the study basin, $25 \%$ of samples were higher than the upper limit of the natural background concentrations $\left(34.8 \mathrm{mg} \mathrm{kg}^{-1}\right)$, and $62 \%$ of samples exceeded the Dutch standard (15 mg kg${ }^{-1}$ ). The $\mathrm{Sb}$ median of $19.2 \mathrm{mg} \mathrm{kg}^{-1}$ was higher than the UCC value. The distribution of $\mathrm{Sb}$ in the stream sediment samples was similar to what was observed for As. Most of the study basin was highly contaminated (Igeo $>5$ ) by $\mathrm{Sb}$, supporting a large $\mathrm{Sb}$ enrichment in the whole basin. The median concentration of $\mathrm{Sb}$ in stream sediments in the study basin was $19 \mathrm{mg} \mathrm{kg}^{-1}$, higher than that found in the contaminated mining sites (range from 5 to $9.8 \mathrm{mg} \mathrm{kg}^{-1}$, respectively, reported by Darwish, 2016; Cortada et al., 2018).

\section{Arsenic}

The concentration of Arsenic varied widely from 0.5 to $1490 \mathrm{mg} \mathrm{kg}^{-1}$; (Table 2), with $46 \%$ of samples having a higher concentration than the upper limit of the natural background. Overall, more than $62 \%$ of all 
Table 1 Pearson correlation coefficients (1) and p values (2) between trace element concentration and $\mathrm{pH}$ in stream sediment samples from the Oued Rarai basin

\begin{tabular}{llllllllllll}
\hline $\mathrm{pH}$ & $\mathrm{Ag}$ & $\mathrm{As}$ & $\mathrm{Cd}$ & $\mathrm{Cr}$ & $\mathrm{Cu}$ & $\mathrm{Hg}$ & $\mathrm{Ni}$ & $\mathrm{Pb}$ & $\mathrm{Sb}$ & $\mathrm{V}$ & $\mathrm{Zn}$ \\
\hline$(1)$ & 0.14 & 0.03 & 0.14 & 0.12 & 0.13 & 0.12 & 0.06 & 0.15 & 0.15 & 0.12 & 0.09 \\
$(2)$ & 0.088 & 0.72 & 0.088 & 0.14 & 0.11 & 0.14 & 0.47 & 0.067 & 0.067 & 0.14 & 0.27 \\
\hline
\end{tabular}

Table 2 Summary statistics of trace element concentrations in stream sediment samples from the Oued Rarai basin plus comparisons with indicative values and geochemical background thresholds

\begin{tabular}{|c|c|c|c|c|c|c|c|c|c|}
\hline \multirow[t]{2}{*}{ Element } & \multicolumn{3}{|c|}{ Summary statistics $\left(\mathrm{mg} \mathrm{kg}^{-1}\right.$, except for $\mathrm{CV}^{*}$ in $\left.\%\right)$} & \multicolumn{5}{|c|}{ Indicative values $\left(\mathrm{mg} \mathrm{kg}^{-1}\right)$} & \multirow{2}{*}{$\begin{array}{l}\text { Geochemical background } \\
\text { threshold }\left(\mathrm{mg} \mathrm{kg}^{-1}\right)\end{array}$} \\
\hline & Mean & $\mathrm{SD}^{*}$ & $\mathrm{CV}^{*}$ & Median & Min & $\operatorname{Max}$ & $\mathrm{UCC}^{\mathrm{a}}$ & $\mathrm{NIL}^{\mathrm{b}}$ & \\
\hline $\mathrm{Ag}$ & 0.36 & 1.12 & 309 & 0.05 & 0.05 & 9.40 & 0.05 & 15 & 0.30 \\
\hline As & 85.8 & 170 & 198 & 45.3 & 0.50 & 1490 & 1.5 & 55 & 47.0 \\
\hline $\mathrm{Cd}$ & 0.64 & 1.14 & 177 & 0.05 & 0.05 & 8.01 & 0.098 & 12 & 1.01 \\
\hline $\mathrm{Cr}$ & 57.4 & 31.4 & 54 & 55.5 & 3.46 & 198 & 35 & 380 & 40.1 \\
\hline $\mathrm{Cu}$ & 22.6 & 10.9 & 48 & 21.0 & 3.85 & 66.8 & 25 & 190 & 23.2 \\
\hline $\mathrm{Hg}$ & 1.54 & 5.56 & 361 & 0.05 & 0.05 & 54.4 & 0.056 & 10 & 0.50 \\
\hline $\mathrm{Ni}$ & 36.7 & 14.2 & 38 & 36.1 & 5.28 & 87.6 & 20 & 210 & 43.1 \\
\hline $\mathrm{Pb}$ & 147 & 531 & 360 & 30.4 & 2.90 & 5150 & 20 & 530 & 36.3 \\
\hline $\mathrm{Sb}$ & 32.1 & 45.2 & 140 & 19.0 & 0.02 & 297 & 0.2 & 15 & 34.8 \\
\hline V & 57.0 & 27.8 & 48 & 52.8 & 6.12 & 148 & 60 & 250 & 49.0 \\
\hline $\mathrm{Zn}$ & 180 & 255 & 141 & 124 & 23.2 & 2610 & 71 & 720 & 144 \\
\hline
\end{tabular}

* $S D$ standard deviation; $C V$ coefficient of variation (\%); $n d$ not determined

aupper continental crust (Taylor \& McLennan, 1985, except for Hg: Wedepohl, 1995)

${ }^{\mathrm{b}}$ Dutch standard for toxic elements in stream sediments (ESDAT, 2013)

sampling sites exceeded the Dutch standard (55 mg kg-1). The As median was $45.3 \mathrm{mg} \mathrm{kg}^{-1}$, largely greater than those found in the contaminated mining sites (Cortada et al., 2018; Darwish, 2016), indicating that a large part of the study basin was enriched in As (Igeo > 5). Arsenic could be released from sulphide minerals (e.g. galena, sphalerite, tetrahedrite, malachite, cinnabar and As-Sb-rich sulfosalts) during mining operation and weathering.

Accordingly, the highest values of As were in correspondence with the mining activities and the siliciclastic sediments of the continental Neogene that covering hilly areas surrounding the Oued Rarai plain.

\section{Cadmium}

Cadmium concentrations in the studied sediments ranged between 0.05 and $8.01 \mathrm{mg} \mathrm{kg}^{-1}$ (Table 2), with $70 \%$ of stream sediment samples characterised by values below $0.1 \mathrm{mg} \mathrm{kg}^{-1}$, which represents the upper limit of the natural background in the study basin. Cadmium concentrations in all samples were within the limits given by the Dutch standard ( $12 \mathrm{mg} \mathrm{kg}^{-1}$ ). As observed for $\mathrm{Ag}$, the highest values of $\mathrm{Cd}$ were measured in stream sediments from Oued Rarai, and its tributaries were the drained mineralised area of the Oued Maaden's abandoned mine, meaning that $\mathrm{Cd}$ concentrations were mostly related to mineral occurrences and mining wastes. Cadmium was abundant in ore minerals at Oued Maaden (Jemmali et al., 2013; Slim-Shimi \& Tlig, 1993). Across Oued Maaden, Cd concentrations in sediments (range from 4 to $5 \mathrm{mg} \mathrm{kg}^{-1}$ ) did not show a downstream decrease, especially in plain samples compared with numerous existing studies (Pascaud et al., 2015; Wolfenden \& Lewin, 1977). The Cd increase could be attributed to the considerable reactivity and mobility of $\mathrm{Cd}^{2+}$ and $\mathrm{Cd}$ (II) species in the solid phase. High $\mathrm{Cd}$ 
contamination (Igeo $>5$ ) occurred in the drainage basin of the Oued Maaden mining site and Oued Rarai plain. Similar average values were recorded in sediments near contaminated sites (Salvarredy-Aranguren et al., 2008; Yacoub, 2014).

\section{Chromium}

Chromium concentrations in sediments ranged from 3.46 to $198 \mathrm{mg} \mathrm{kg}^{-1}$ (Table 2), with an upper limit of natural background $\left(40.1 \mathrm{mg} \mathrm{kg}^{-1}\right)$ close to the corresponding UCC value ( $35 \mathrm{mg} \mathrm{kg}^{-1}$ ). All samples had $\mathrm{Cr}$ concentration under the Dutch standard (380 $\mathrm{mg} \mathrm{kg}^{-1}$ ). The highest values occurred mainly in clayey deposits in hilly areas and alluvial plain. Moderate contamination $(1<$ Igeo $<3)$ characterised most samples from the study basin. Chromium concentrations observed in the Oued Rarai basin fell within the range found in the literature (range from 39.80 to $148 \mathrm{mg} \mathrm{kg}^{-1}$, respectively, reported by Zuluaga et al., 2016 and Shruti et al., 2013).

\section{Copper}

Copper concentrations in Oued Rarai sediments ranged from 3.58 to $66.8 \mathrm{mg} \mathrm{kg}^{-1}$ (Table 2), with an upper limit of natural background of $23.2 \mathrm{mg} \mathrm{kg}^{-1}$, relatively comparable to the corresponding UCC value $\left(25 \mathrm{mg} \mathrm{kg}^{-1}\right)$. In the study basin, 9\% of samples exceeded the upper limit of the natural background, and all stream sediment samples had $\mathrm{Cu}$ concentration under the Dutch standard $\left(190 \mathrm{mg} \mathrm{kg}^{-1}\right)$. The highest $\mathrm{Cu}$ concentrations were found in the drainage basin of the Oued Maaden mining site, mineralised areas (e.g. Arko-Hafer, Thuburnic). Low contamination (Igeo <

1) characterised the whole study basin. Copper median concentrations in this study were significantly lower (i.e. 5-8 times) than concentrations observed in others mining districts (Cortada et al., 2018; Salvarredy-Aranguren et al., 2008).

\section{Lead}

Lead concentrations in Oued Rarai sediments ranged from 2.9 to $5150 \mathrm{mg} \mathrm{kg}^{-1}$ (Table 2), with an upper limit of natural background of $36.3 \mathrm{mg} \mathrm{kg}^{-1}$, slightly above the corresponding UCC value $\left(20 \mathrm{mg} \mathrm{kg}^{-1}\right)$. In the study area, $41 \%$ of samples were above the upper limit of the natural background. Although the mean concentration of $\mathrm{Pb}$ was below the Dutch standard (530 mg kg $\mathrm{k}^{-1}$ ), $\mathrm{Pb}$ concentrations in seven stream sediment samples surpassed the Dutch standard, with an average factor of 3.7. Elevated $\mathrm{Pb}$ concentrations were observed in the drainage basin of the Oued Maaden mining site. Lead concentrations showed a similar pattern as observed for $\mathrm{Hg}\left(r^{2}=0.85\right) ; \mathrm{Pb}$ concentrations in sediments did not show a downstream decrease (Hudson-Edwards et al., 2001; Lecce $\&$ Pavlowsky, 2014). Indeed, high $\mathrm{Pb}$ contamination (Igeo > 5) was in correspondence with that of $\mathrm{Hg}$ : the drainage basin of the Oued Maaden mining site and tributaries cutting NE-SW trending faults. If the $\mathrm{Pb}$ enrichment around the mining site was probably due to the ore-related activities as reported by several studies (Oyarzun et al., 2011; Pascaud et al., 2015; Salvarredy-Aranguren et al., 2008), the heterogeneity of $\mathrm{Pb}$ concentrations observed in plain samples implied the presence of additional sources along the river. The lead median value was twice higher than that found in the stream sediments from Oued Mellègue, northern Tunisia (14 mg kg-1, Mlayah et al., 2009). In contrast, higher concentrations of $\mathrm{Pb}\left(700 \mathrm{mg} \mathrm{kg}^{-1}\right)$ were reported in the sediments of Oued Ghezini, which drains the Jalta $\mathrm{Pb}-\mathrm{Zn}$ mine in northern Tunisia (Pascaud et al., 2015).

\section{Mercury}

Mercury concentrations in the sediments from the Oued Rarai basin ranged from 0.05 to $54.4 \mathrm{mg} \mathrm{kg}^{-1}$ (Table 2), with most of the studied samples (80\%) exhibiting values below $0.5 \mathrm{mg} \mathrm{kg}^{-1}$, which represents the upper limit of the natural background in the study basin. Only 10 stream sediment samples had concentrations of $\mathrm{Hg}$, which exceeded the Dutch standard $\left(10 \mathrm{mg} \mathrm{kg}^{-1}\right)$. The highest values of $\mathrm{Hg}$ concentrations were observed downstream a large abandoned open-pit developed in $\mathrm{Hg}$ deposits. Therefore, the high $\mathrm{Hg}$ concentrations could be attributed to the ore-related operations of the former $\mathrm{Hg}$ mine, which led to particulate inputs in Oued Maaden. As observed for $\mathrm{Cd}, \mathrm{Hg}$ concentrations in sediments from Oued Maaden dropped dramatically in the sediment samples located less than $80 \mathrm{~m}$ from the mining sites but then increased up to $21 \mathrm{mg} \mathrm{kg}^{-1}$ in samples collected along the lower stretch of Oued Maaden before the Ghardimaou plain. 
The lack of a decrease in the contaminant concentration downstream the pollution source is typical for historical primary pollution. The cleaner particulates from reaches upstream the historical sources have continuously diluted the primary contamination. It is noteworthy that $\mathrm{Hg}$ concentrations were below the detection limit $\left(0.05 \mathrm{mg} \mathrm{kg}^{-1}\right)$ along Oued Rarai, except for two samples located at the confluence of Oued Maaden. Tributaries cutting NE-SW trending faults also showed significant $\mathrm{Hg}$ concentrations. The drainage basin of the Oued Maaden mining site and tributaries cutting some NE-SW trending faults were characterised by high $\mathrm{Hg}$ contaminations (Igeo $>5$ ). The mercury median value was $10-50$ times lower than those observed near the Punitaqui $\mathrm{Cu}-\mathrm{Au}-\mathrm{Hg}$ mine in Chile ( $\mathrm{Hg}$ concentration in stream sediment range from 0.2 to $3.6 \mathrm{mg} \mathrm{kg}^{-1}$, Higueras et al., 2004) and Kalecik and Palawan Quicksilver $\mathrm{Hg}$ mines in the Philippines (range from 3.5 to $52 \mathrm{mg} \mathrm{kg}^{-1}$, Gray et al., 2003).

\section{Nickel}

Nickel concentrations in samples ranged from 5.28 to $87.6 \mathrm{mg} \mathrm{kg}^{-1}$ (Table 2), below the Dutch standard $\left(210 \mathrm{mg} \mathrm{kg}^{-1}\right)$. Approximatively, $28 \%$ of samples presented values higher than the upper limit of the natural background $\left(43.1 \mathrm{mg} \mathrm{kg}^{-1}\right)$. The $\mathrm{Ni}$ median value was $\left(36 \mathrm{mg} \mathrm{kg}^{-1}\right)$, higher than the corresponding UCC value $\left(20 \mathrm{mg} \mathrm{kg}^{-1}\right)$, indicating a substantial $\mathrm{Ni}$ enrichment. The whole Oued Rarai basin was mainly characterised by a moderate Ni contamination, with the highest contamination level recorded in correspondence with the Neogene siliciclastic sediments in hilly areas. Nickel concentrations were higher than the values found in the literature (range from 3.5 to $25 \mathrm{mg} \mathrm{kg}^{-1}$, respectively, reported by Gray et al., 2003, Morillo et al., 2002 and Cortada et al., 2018). As for the chromium and vanadium concentrations, even in this case, the felsic plugs and mafic dikes, sills and basaltic flows which crosscut the nappe pile of the Kroumirie chain may represent relevant geogenic sources.

\section{Silver}

In the Oued Rarai basin, $\mathrm{Ag}$ concentrations in stream sediments ranged from 0.05 to $9.4 \mathrm{mg} \mathrm{kg}^{-1}$ (Table 2), with most of the samples (76.3\% of total samples) characterised by concentrations lower than the upper limit of the natural background of $0.3 \mathrm{mg} \mathrm{kg}^{-1}$. In total, $23 \%$ of stream sediments had concentrations higher than the UCC value $\left(0.05 \mathrm{mg} \mathrm{kg}^{-1}\right)$ reported by Taylor and McLennan (1985), and all samples showed Ag concentrations below the intervention value ( $15 \mathrm{mg} \mathrm{kg}^{-1}$ ) established by the Dutch standard (ESDAT, 2013). The highest concentrations (from 4 to $9.4 \mathrm{mg} \mathrm{kg}^{-1}$ ) were measured in the mineralised area of the Oued Maaden $\mathrm{Pb}-\mathrm{Zn}$ and $\mathrm{Hg}$ mines, where values were up to 184 times higher than those of the UCC. Relatively high concentrations were also observed in the Oued Maaden plain samples. Spatial distribution of Igeo indicated that a large part of the study basin was characterised by high Ag contaminations (Igeo $>5$ ). The high Ag contamination, mainly in correspondence with the drainage basin of the Oued Maaden mining site and Oued Rarai plain. Following numerous previous studies, high Ag concentrations can be related to former mining activities at Oued Maaden, which was responsible for the release of several millions of tons of tailings in the drainage basin (Ferreira da Silva et al., 2015; Oyarzun et al., 2011). Silver concentrations (range from 0.05 to $9.40 \mathrm{mg} \mathrm{kg}^{-1}$ ), however, were 10-100 times lower than those observed in mining sites worldwide (Cortada et al., 2018; Ferreira da Silva et al., 2015; Oyarzun et al., 2011).

\section{Vanadium}

The concentration of vanadium varied widely from 6.12 to $148 \mathrm{mg} \mathrm{kg}^{-1}$, with an upper limit of the natural background of $49 \mathrm{mg} \mathrm{kg}^{-1}$ (Table 2), slightly lower than the corresponding UCC value $\left(60 \mathrm{mg} \mathrm{kg}^{-1}\right)$. In total, $53 \%$ of samples exceeded the upper limit of the natural background, and all samples had a $\mathrm{V}$ concentration below the Dutch standard $\left(250 \mathrm{mg} \mathrm{kg}^{-1}\right)$. The highest values of $\mathrm{V}$ concentrations were observed close to the Oued Maaden mine. A low V contamination (Igeo $<1$ ) characterised the whole study basin. Median concentrations of $\mathrm{V}$ were relatively comparable to those found in the literature (range from 45 to $53 \mathrm{mg} \mathrm{kg}^{-1}$, respectively, reported by Zuluaga et al., 2016; Shruti et al., 2013). 
Zinc

Zinc concentrations ranged from 23.2 to $2610 \mathrm{mg} \mathrm{kg}^{-1}$, with an upper limit of the natural background of $144 \mathrm{mg} \mathrm{kg}^{-1}$, higher than the UCC value $\left(71 \mathrm{mg} \mathrm{kg}^{-1}\right.$ ) (Table 2). In this study basin, $35 \%$ of sediments exceeded the upper limit of the natural background, and only four samples were higher than the Dutch standard $\left(720 \mathrm{mg} \mathrm{kg}^{-1}\right)$. The highest $\mathrm{Zn}$ concentrations were mainly found in the stream sediment samples from the Oued Maaden's abandoned mine. Some tributaries cutting the NE-SW trending faults also revealed significant $\mathrm{Zn}$ concentrations. Distribution of the Igeo displayed high $\mathrm{Zn}$ contamination (Igeo $>3$ ) occurring close to ore deposits, showings and tectonic contacts, while the rest of the study basin was weakly to moderately contaminated $($ Igeo $<2)$. The measure $\mathrm{Zn}$ concentrations were similar to the average values observed in mining sites in Peru (160 mg kg-1, Yacoub et al., 2014), Chile (180 $\mathrm{mg} \mathrm{kg}^{-1}$ Higueras et al., 2004) and Spain (155 $\mathrm{mg} \mathrm{kg}^{-1}$ Arias et al., 2012).

\section{Risk assessment}

The potential ecological risk was assessed using the RI to identify trace elements posing environmental risk (Fig. 3). On average, $E_{i}$ values were maximum for As with a median of 302 , indicating a very high to serious ecological risk $(>160)$. Such high values were found in most sampling sites (77\% of the data set). Arsenic contamination was more severe in the Oued Rarai basin than other regions of Tunisia where the median $E_{i}$ of As reached three times that in the Nefza region (Ayari et al., 2016), which corroborates the Igeo results. Considering the absence of $\mathrm{Sb}$ and $\mathrm{Ag}$ in the current $E_{i}$ calculations, As appeared as the principal trace element responsible for the ecological risk in the study area, followed by $\mathrm{Cd}, \mathrm{Hg}$ and $\mathrm{Pb}$. Indeed, $\mathrm{E}_{\mathrm{i}}$ factor reached locally very high values for $\mathrm{Cd}, \mathrm{Hg}$ and $\mathrm{Pb}$, with $29 \%, 21 \%$ and $16 \%$ of data points being $>$ 40, respectively (Fig. 3). Conversely, $\mathrm{E}_{\mathrm{i}}$ for $\mathrm{Cr}, \mathrm{Cu}$, $\mathrm{Ni}, \mathrm{V}$ and $\mathrm{Zn}$ never exceeded 40.

Considering all studied trace elements, RI results showed that $81 \%$ of all sampling sites posed considerable to very high ecological risks (RI > 300), which were more critical than other regions in northern Tunisia (Ayari et al., 2016). We assume that the Oued Rarai basin has had significant toxicological and ecotoxicological impacts on natural ecosystems. Sediment samples with higher ecological risks were found in the tributaries crossing the tectonic contact and the drainage basin of the Oued Maaden mine. These observations agreed with the distribution patterns of concentrations and Igeo of trace elements. Thus, both natural lithogenic and mining activities were considered the main factors controlling trace element contamination.

Source identification and apportion contributions

A PCA was applied to investigate the correlations among trace element concentrations in sediments from the Oued Rarai basin in reduced dimensions. The resulting first three principal components accounted for $74 \%$ of the total data variance (Table 3 ). The first principal component (PC1, 34\% of the total data variance) explained $\mathrm{Cr}, \mathrm{Ni}, \mathrm{V}$ and $\mathrm{Cu}$ with the strongest positive scores and $\mathrm{Hg}$ with the negative ones (Table 3 and Fig. 4). In this case, the felsic plugs and mafic dikes, sills and basaltic flows which crosscut the nappe pile of the Kroumirie chain may represent relevant geogenic sources.

Negative loading of $\mathrm{Hg}$ in $\mathrm{PC} 1$ reflected different sources and depositional environments of $\mathrm{Hg}$ and $\mathrm{Cr}-$ $\mathrm{V}-\mathrm{Cu}-\mathrm{Ni}$. Historically, the Oued Maaden area included an ancient $\mathrm{Hg}$ mine, suggesting that $\mathrm{Hg}$ in sediments can be attributed to mining operations and the weathering of abandoned wastes (Higueras et al., 2004; Gemici et al., 2013). The second principal component (PC2, 26\% of the total data variance) explained $\mathrm{Ag}$ and $\mathrm{Cd}$ with positive scores and $\mathrm{As}$ and $\mathrm{Sb}$ with negative ones (Table 3 and Fig. 4). This last grouping, as well as high concentrations previously reported for $\mathrm{As}$ and $\mathrm{Sb}$, agreed with data from the National Office of Mines, Tunisia, and other studies (Rouvier et al., 1985), suggesting that northwest of Tunisia is characterised by As and $\mathrm{Sb}$ geochemical haloes (Fig. 5). Indeed, northern Tunisia contains several $\mathrm{Pb}-\mathrm{Zn}$ deposits with $\mathrm{As}$ and $\mathrm{Sb}$ enrichments associated with Neogene siliciclastic sediments, such as Bou Aouane, Bazina and La Semene (Rouvier et al., 1985). According to Bouaziz et al. (2002), the paleocatchment of Oued Rarai was coincident in the depositional environments of detrital sediments during Miocene. In the sediments, As and $\mathrm{Sb}$ were better adsorbed by oxyhydroxides than by clay minerals, as 


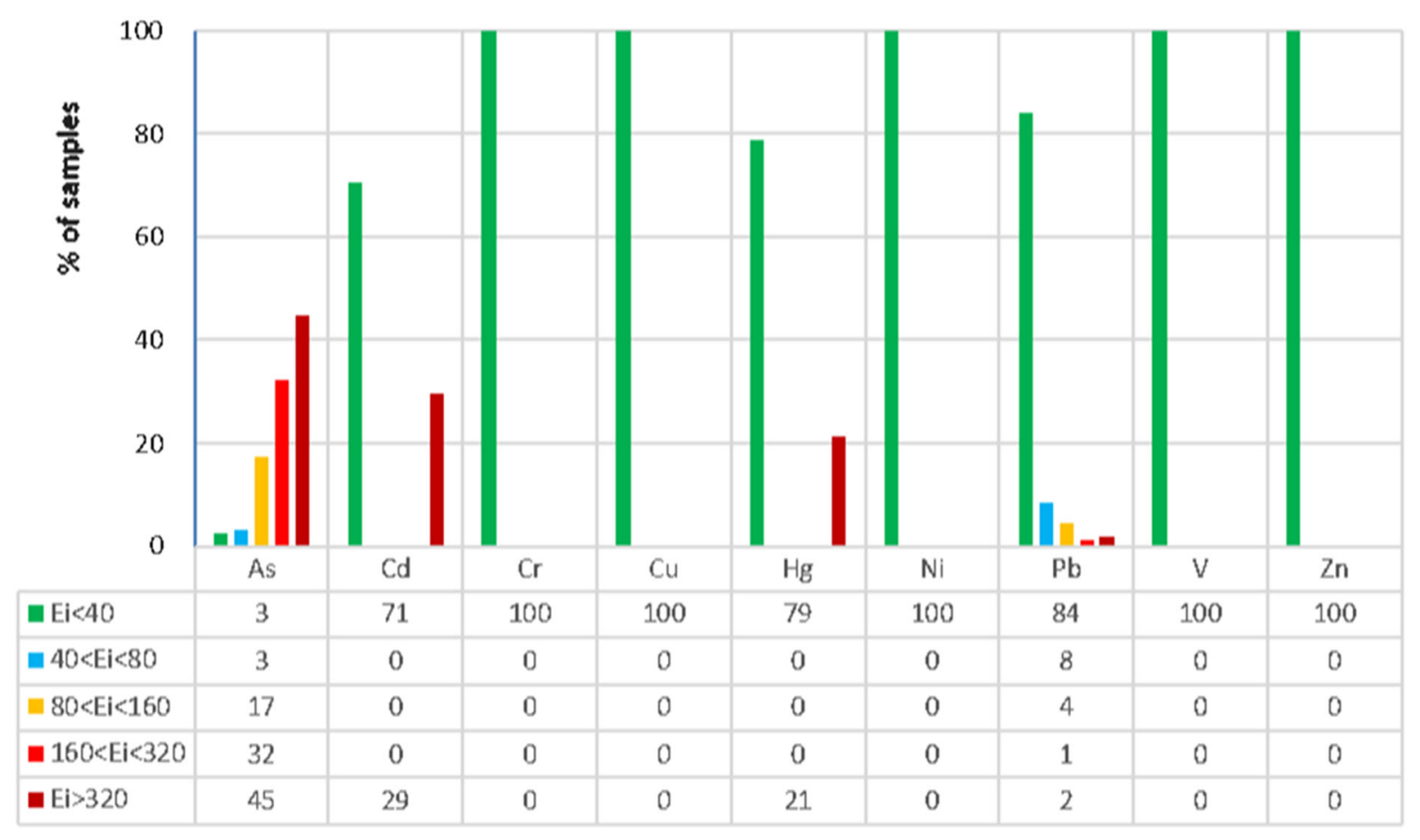

Fig. 3 Potential ecological risk factor $(E i)$ of nine trace elements in the study basin

Table 3 Scores of the first three principal components (PC) from the PCA based on trace element concentrations in stream sediments from the Oued Rarai basin

\begin{tabular}{lccl}
\hline Element & PC1 & PC2 & PC3 \\
\hline $\mathrm{V}$ & 0.91 & 0.20 & -0.07 \\
$\mathrm{Cr}$ & 0.89 & 0.05 & -0.11 \\
$\mathrm{Ni}$ & 0.86 & -0.42 & -0.05 \\
$\mathrm{Cu}$ & 0.85 & -0.07 & -0.07 \\
$\mathrm{Hg}$ & -0.63 & 0.22 & -0.29 \\
$\mathrm{Cd}$ & 0.05 & 0.91 & -0.09 \\
$\mathrm{Ag}$ & 0.07 & 0.78 & -0.19 \\
$\mathrm{As}$ & -0.04 & -0.58 & -0.28 \\
$\mathrm{Sb}$ & -0.42 & -0.82 & 0.05 \\
$\mathrm{~Pb}$ & -0.18 & 0.38 & 0.83 \\
$\mathrm{Zn}$ & 0.31 & -0.20 & 0.82 \\
Eigenvalue & 3.79 & 2.90 & 1.59 \\
Data variance $(\%)$ & 34 & 26 & 14 \\
\hline
\end{tabular}

reported in many studies (e.g. Leuz et al., 2006; Smedley \& Kinniburgh, 2002).

The inverse correlation between $\mathrm{As}-\mathrm{Sb}$ and $\mathrm{Ag}-\mathrm{Cd}$ supports the presence of distinct sources and patterns.

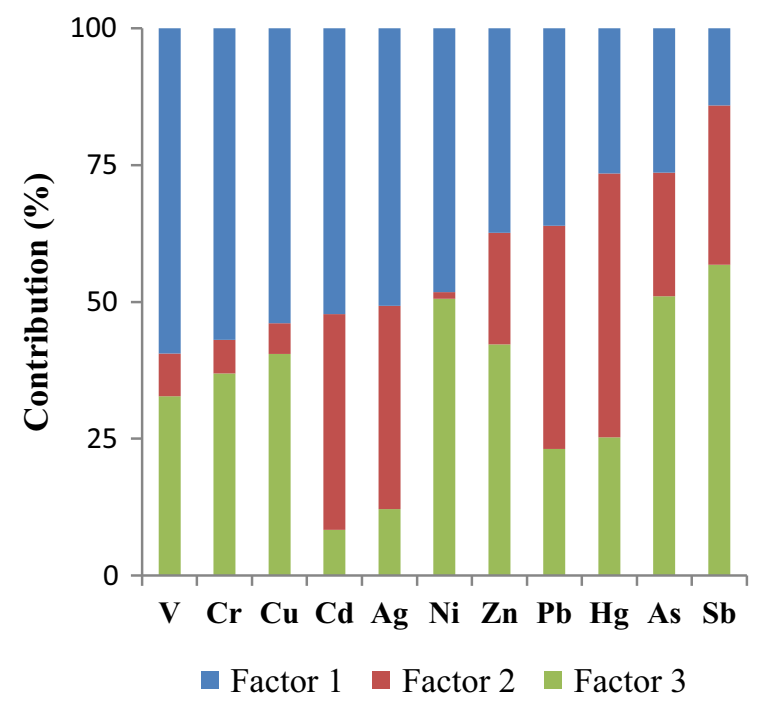

Fig. 4 The contribution of the three identified factors

First, Ag and Cd could be controlled by historical mining activities occurring in the study basin, because they are found as minor components in ore minerals (Slim-Shimi \& Tlig, 1993). Second, Ag and Cd were more associated with fine-grained particles deposited 


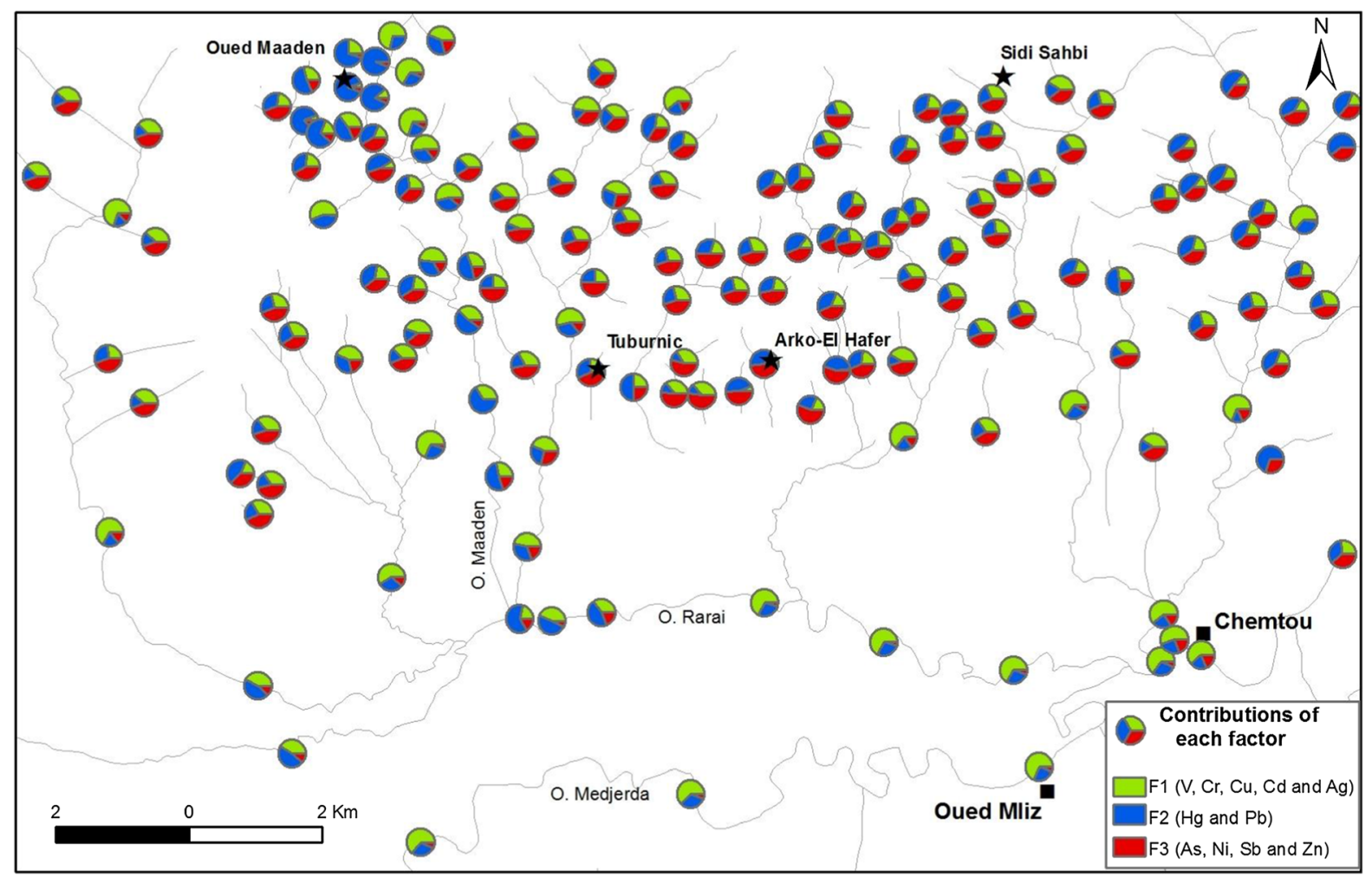

Fig. 5 The contribution of the three identified factors to the investigated trace elements in the Oued Rarai basin

in the alluvial plain, as highlighted by many authors (e.g. Cossa et al., 2014; Zuzolo et al., 2016).

Finally, the third principal component (PC3, 14\% of the total data variance) explained both $\mathrm{Pb}$ and $\mathrm{Zn}$ with positive scores (Table 3 and Fig. 4). The highest concentrations for both $\mathrm{Pb}$ and $\mathrm{Zn}$ occurred in the drainage basin of the Oued Maaden mine and along some tributaries cutting the tectonic contact in the hilly area. Therefore, $\mathrm{Pb}$ and $\mathrm{Zn}$ (Fig. 5) seemed to be mainly controlled by mining operations, especially downstream mining sites (Arias et al., 2012; Salvarredy-Aranguren et al., 2008).

Past flooding events had served to deposit coarse fractions containing $\mathrm{Hg}$ and $\mathrm{Pb}$ in the alluvial plain. The contaminated sediments in the lower land were masked by fine particles rich with $\mathrm{V}, \mathrm{Cr}, \mathrm{Cu}, \mathrm{Cd}$ and Ag. The contaminated sediments were deposited during the low-energy hydrological environment while, in the relatively higher land, the coarse sediments remained on the surface. Today, deeper contaminated sediments can be resuspended by the surface run-off during heavy rainfalls, constituting a potential secondary source for trace element contamination in the floodplain (Axtmann \& Luoma, 1991; Moore et al., 1989). Sediments deposited in the higher land were eroded during severe flood discharges and were returned to the river sediments by tributaries (Macklin \& Lewin, 1989; Miller et al., 1999). These findings confirm that the erosion and deposition of materials, deriving from rocks hosting mineralised vein bodies exposed in the paleo-watershed system, were the dominant sources for the higher concentrations of these elements.

\section{Conclusions}

A total of 156 stream sediment samples collected from the Oued Rarai basin in northern Tunisia were analysed to determine the total concentration of trace elements ( $\mathrm{As}, \mathrm{Cd}, \mathrm{Cr}, \mathrm{Cu}, \mathrm{Ni}, \mathrm{Pb}, \mathrm{Sb}, \mathrm{V}$ and $\mathrm{Zn}$ ) to identify both contamination levels and sources of these potentially toxic elements. Based on total concentrations and Igeo, the stream sediments were contaminated by trace elements to different degrees. The contamination level reported in this study 
indicates a non-negligible potential ecological risk, mainly related to sediment transport along the river. Antimony and arsenic have been identified as principal contaminants exceeding the Dutch standard for $62 \%$ and $40 \%$ of all sampling sites, respectively. Results from correlation analysis and principal component analysis revealed three main geochemical associations related to lithologic, tectonic and anthropogenic sources. $\mathrm{V}, \mathrm{Cr}, \mathrm{Ni}$ and $\mathrm{Cu}$ mainly originated from natural bedrock and soil. $\mathrm{Ag}$ and $\mathrm{Cd}$ were more controlled by mining enrichments. $\mathrm{Ag}, \mathrm{Hg}$ and $\mathrm{Pb}$ were mostly influenced by the ancient ore-related activities at the Oued Maaden site and NE-SW trending faults. Finally, $\mathrm{Sb}$, As, and $\mathrm{Zn}$ were largely controlled by the siliciclastic continental Neogene sequences.

The concentrations and patterns of trace elements in the study basin were mostly controlled by the physical and chemical dynamics of the watershed system, lithological properties, mineralisation, tectonic settings and mobilisation of subsurface sediments. The large flooding events similar to those in the Mediterranean region in recent years play a crucial role in the remobilisation of some trace elements from historically mining polluted deposits, whereas present-day pollutants are primarily transported during moderate and low flows. To prevent river pollution and improve the watershed ecosystem health, it is important to understand clearly the contamination characteristics of trace elements in sediments, soils and vegetation and target their potential source.

The current findings could inform environmental risk management of the studied contaminants on a catchment scale.

Acknowledgements On behalf of all the authors, I, as the corresponding author declare that they have no conflict of interest. The Tunisian National Office of Mines financially supported this research. The authors are also grateful to Mohamed Bensalem for his encouragement and support. All data generated or analysed during this study are included in this published article (and its supplementary information files). Authors make substantial contributions to conception and design, acquisition analysis and interpretation of data. Authors participate in drafting the article or revising it critically for important intellectual content; and Authors give final approval of the version to be submitted and any revised version: animal research, consent to participate and consent to publish not applicable. This research was financially supported by the Tunisian National Office of Mines. The authors are also grateful to Mohamed Bensalem for his encouragement and support.
Open Access This article is licensed under a Creative Commons Attribution 4.0 International License, which permits use, sharing, adaptation, distribution and reproduction in any medium or format, as long as you give appropriate credit to the original author(s) and the source, provide a link to the Creative Commons licence, and indicate if changes were made. The images or other third party material in this article are included in the article's Creative Commons licence, unless indicated otherwise in a credit line to the material. If material is not included in the article's Creative Commons licence and your intended use is not permitted by statutory regulation or exceeds the permitted use, you will need to obtain permission directly from the copyright holder. To view a copy of this licence, visit http://creativecommons.org/licenses/by/4.0/.

Funding Open access funding provided by Università degli Studi di Roma La Sapienza within the CRUI-CARE Agreement.

\section{References}

Argyraki, A., Kelepertzis, E., Botsou, F., Paraskevopoulou, V., Katsikis, I., \& Trigoni, M. (2018). Environmental availability of trace elements $(\mathrm{Pb}, \mathrm{Cd}, \mathrm{Zn}, \mathrm{Cu})$ in soil from urban, suburban, rural and mining areas of Attica. Hellas Journal of Geochemical Exploration, 187(2018), 201-213. https://doi.org/10.1016/j.gexplo.2017.09.004

Arias, M., Gumiel, P., \& Martín-Izard, A. (2012). Multifractal analysis of geochemical anomalies: A tool for assessing prospectivity at the SE border of the Ossa Morena Zone, Variscan Massif (Spain). Journal of Geochemical Exploration, 122, 101-112. https://doi.org/10.1016/j.gexplo. 2012.08.007

Ayari, A., Agnan, Y., \& Charef, A. (2016). Spatial assessment and source identification of trace metal pollution in stream sediments of Oued El Maadene basin, northern Tunisia. Environmental Monitoring and Assessment, 188, 397. https://doi.org/10.1007/s10661-016-5402-4

Axtmann, E. V., \& Luoma, S. N. (1991). Large-scale distribution of metal contamination in fine-grained sediments of the Clark Fork River, Montana, USA. Applied Geochemistry, 6, 75-88. https://doi.org/10.1016/08832927(91)90064-V

Baize, D., \& Sterckeman, T. (2001). Of the necessity of knowledge of the natural pedo-geochemical background content in the evaluation of the contamination of soils by trace elements. Science of the Total Environment, 264, 127-139. https://doi.org/10.1016/S0048-9697(00)00615$\mathrm{X}$

Barbieri, M., Sappa, G., \& Nigro, A. (2018). Soil pollution: Anthropogenic versus geogenic contributions over large areas of the Lazio region. Journal of Geochemical Exploration, 195, 78-86. https://doi.org/10.1016/j.gexplo.2017. 11.014

Barbieri, M., Sappa, G., Vitale, S., Parisse, B., \& Battistel, M. (2014). Soil control of trace metals concentrations in landfills: a case study of the largest landfill in Europe, Malagrotta, Rome. Journal of Geochemical Exploration, 
143, 146-154. https://doi.org/10.1016/j.gexplo.2014.04. 001

Bouaziz, S., Barrier, E., Soussi, M., Turki, M. M., \& Zouari, H. (2002). Tectonic evolution of the northern African margin in Tunisia from paleostress. Tectonophysics. https://doi. org/10.1016/S0040-1951(02)00370-0.

Boussen, S., Soubrand, M., Bril, H., Ouerfelli, K., \& Abdeljaouad, S. (2013). Transfer of lead, zinc and cadmium from mine tailings to wheat (Triticum aestivum) in carbonated Mediterranean (Northern Tunisia) soils. Geoderma, 192, 227-236.

Chen, H., Chen, R., Teng, Y., \& Wu, J. (2016). Contaminxation characteristics, ecological risk and source identification of trace metals in sediments on the Lean River (China). Ecotox Environ Safe, 125, 82-85. https://doi.org/10.1016/j. ecoenv.2015.11.042

Clement, A. J. H., Nováková, T., Hudson-Edwards, K. A., Fuller, I. C., Macklin, M. G., Fox, E. G., \& Zapico, I. (2017). The environmental and geomorphological impacts of historical gold mining in the Ohinemuri and Waihou river catchments, Coromandel, New Zealand. Geomorphology, 295, 159-175. https://doi.org/10.1016/j. geomorph.2017.06.011

Cortada, U., Hidalgo, M. C., Martínez, J., \& Rey, J. (2018). Dispersion of metal(loid)s in fluvial sediments: An example from the Linares mining district (southern Spain). Int J Environ Sci Te. https://doi.org/10.1007/s13762-018-1687$\mathrm{X}$

Cossa, D., Buscail, R., Puig, P., Chiffoleau, J. F., Radakovitch, O., Jeanty, G., \& Heussner, S. (2014). Origin and accumulation of trace elements in sediments of the northwestern Mediterranean margin. Chemical Geology, 380, 61-73. https://doi.org/10.1016/j.chemgeo.2014.04.015

Daldoul, G., Souissi, R., Souissi, F., Jemmali, N., \& Chakroun, H. K. (2015). Assessment and mobility of heavy metals in carbonated soils contaminated by old mine tailings in North Tunisia. J Afr Earth Sci, 110, 150-159. https://doi. org/10.1016/j.jafrearsci.2015.06.004

Darwish, M. A. G. (2016). Stream sediment geochemical patterns around an ancient gold mine in the Wadi El Quleib area of the Allaqi region, south Eastern Desert of Egypt: Implications for mineral exploration and environmental studies. Journal of Geochemical Exploration. https://doi. org/10.1016/j.gexplo.2016.10.010

Decrée, S., Baele, J. M., De Putter, Th., Yans, J., Clauer, N., Dermech, M., Aloui, K., \& Marignac, Ch. (2013). The Oued Belif hematite-rich breccia (Nefza Mining District, NW Tunisia): A potential candidate for a Miocene small scale iron oxide copper gold (IOCG) deposit in Northern Tunisia. Economic Geology, 108, 1425-1457.

ESDAT, 2013. Dutch target and intervention values, 2000 (the NewDutch list). VROM: Former ministry of housing, spatial planning and the environment (presently Ministry of Infrastructure and the Environment). https://www.esdat. net/Environmental\%20Standards/Dutch/annexS I2000Dutch\%20Environmental\%20Standards.pdf

Ferreira da Silva, E., Durães, N., Reis, P., Patinha, C., \& Costa, M. R. (2015). An integrative assessment of environmental degradation of Caveira abandoned mine area (Southern Portugal). Journal of Geochemical Exploration. https:// doi.org/10.1016/j.gexplo.2015.08.004
Gaume, E., Bain, V., Bernardara, P., et al. (2009). A collation of data on European flash floods. Journal of Hydrology, 367, 70-78. https://doi.org/10.1016/j.jhydrol.2008.12.028

Gemici, U., \& Oyman, T. (2013). The influence of the abandoned Kalecik $\mathrm{Hg}$ mine on water and stream sediments (Karaburun, Izmir, Turkey). Science of the Total Environment, 312, 155-166. https://doi.org/10.1016/S00489697(03)00008-1

Goodbred, S. L., \& Kuehl, S. A. (1998). Floodplain processes in the Bengal Basin and storage of Ganges-Brahmaputra river sediment: An accretion study using $137 \mathrm{Cs}$ and $210 \mathrm{~Pb}$ geochronologies. Sedimentary Geology, 121, 239-258. https://doi.org/10.1016/S0037-0738(98)00082-7

Gray, J. E., Greaves, I. A., Bustos, D. M., \& Krabbenhoft, D. P. (2003). Mercury and methylmercury contents in minewaste calcine, water, and sediment collected from the Palawan Quicksilver Mine, Philippines. Environmental Geology, 43, 298-307.

Guellala, R., Tagorti, M. A., Inoubli, M. H., \& Faouzi, A. (2012). Insights into Mejerda basin hydrogeology, Tunisia. Appl Water Sc, 2, 143-155. https://doi.org/10.1007/ s13201-012-0038-1

Hakanson, L. (1980). Ecological risk index for aquatic pollution control. A sedimentological approach. Water Research, 14, 975-1001. https://doi.org/10.1016/0043-1354(80)90143-8

Higueras, P., Oyarzun, R., Oyarzun, J., Maturana, H., Lillo, J., \& Morata, D. (2004). Environmental assessment of coppergold-mercury mining in the Andacollo and Punitaqui districts, northern Chile. Applied Geochemistry, 19, 1855-1864.

Hudson-Edwards, K. A., Macklin, M. G., Miller, J. R., \& Lechler, P. J. (2001). Sources, distribution and storage of heavy metals in the Rio Pilcomayo, Bolivia. Journal of Geochemical Exploration, 72, 229-250. https://doi.org/10. 1016/S0375-6742(01)00164-9

INM, 2003. Archives de l'Institut National de Météorologie, région de Jendouba pour la période 1992-2002.

Jallouli, C., Mickus, K., Turki, M. M., \& Rihane, C. (2003). Gravity and aeromagnetic constraints on the extent of Cenozoic volcanic rocks within the Nefza-Tabarka region, northwestern Tunisia. Journal of Volcanology and Geothermal Research, 122, 51-68. https://doi.org/10. 1016/S0377-0273(02)00469-9

Jemmali, N., Souissi, F., Carranza, J. E. M., \& Bouabdellah, M. (2013). Lead and sulfur isotope constraints on the genesis of the polymetallic mineralization at Oued Maden. Jebel Hallouf and Fedj Hassene carbonate-hosted $\mathrm{Pb}-\mathrm{Zn}$ (As$\mathrm{Cu}-\mathrm{Hg}-\mathrm{Sb}$ ) deposits. Northern Tunisia. Journal of Geochemical Exploration, 132, 6-14. https://doi.org/10.1016/j. gexplo.2013.03.004

Khalil, A., Hanich, L., Bannari, A., Zouhri, L., Pourret, O., \& Hakkou, R. (2013). Assessment of soil contamination around an abandoned mine in a semi-arid environment using geochemistry and geostatistics: Pre-work of geochemical process modeling with numerical models. Journal of Geochemical Exploration, 125, 117-129. https://doi. org/10.1016/j.gexplo.2012.11.018

Lecce, S. A., \& Pavlowsky, R. T. (2014). Floodplain storage of sediment contaminated by mercury and copper from historic gold mining at Gold Hill, North Carolina, USA. 
Geomorphology, 206, 122-132. https://doi.org/10.1016/j. geomorph.2013.10.004

Lecce, S. A., \& Pavlowsky, R. T. (1997). Storage of miningrelated zinc in floodplain sediments, Blue River, Wisconsin. Phys Geog, 18, 424-439. https://doi.org/10.1080/ 02723646.1997.10642628

Leuz, A. K., Monch, H., \& Johnson, C. A. (2006). Sorption of $\mathrm{Sb}(\mathrm{III})$ and $\mathrm{Sb}(\mathrm{V})$ to Goethite: Influence on $\mathrm{Sb}(\mathrm{III})$ oxidation and mobilization. Environmental Science and Technology, 40, 7277-7282. https://doi.org/10.1021/es061284b

Li, L., Tu, H., Zhang, S., Wu, L., Wu, M., Tang, Y., \& Wu, P. (2019). Geochemical behaviors of antimony in miningaffected water environment (Southwest China). Environmental Geochemistry and Health, 41, 2397-2411. https:// doi.org/10.1007/s10653-019-00285-8

Llassat, M.C., Llasat-Botija, M., Prat, M.A., 2010. High-impact floods and flash floods in Mediterranean countries: the flash preliminary database. Advances in Geosciences 23, 1-9. www.adv-geosci.net/23/47/2010/

Loukil, C., 1994. Prospection géochimique stratégique de la feuille Ghardimaou au 1/50000. Rapport Interne 429, Office National des Mines.

Luís, A. T., Grande, J. A., Durães, N., Davila, L. M., Santisteban, M., Almeida, S. F. P., Sarmiento, A. M., De la Torre, M. L., Fortes, J. C., \& Ferreira da Silva, E. (2019). Biogeochemical characterization of surface waters in the Aljustrel mining area (South Portugal). Environmental Geochemical and Health, 41, 1909-1921.

Macklin, M. G., \& Lewin, J. (1989). Sediment transfer and transformation of an alluvial valley floor: the river South Tyne, Northumbria, UK. Earth Surface Processes and Landforms, 14, 233-246. https://doi.org/10.1002/esp. 3290140305

Macklin, M. G., Brewer, P. A., Hudson-Edwards, K. A., Bird, G., Coulthard, T. J., Dennis, I. A., Lechler, P. J., Miller, J. R., \& Turner, J. N. (2006). A geomorphological approach to the management of rivers contaminated by metal mining. Geomorphology, 79, 423-447. https://doi.org/10. 1016/j.geomorph.2006.06.024

Matschullat, J., Ottenstein, R., \& Reimann, C. (2000). Geochemical background-can we calculate i t? Environmental Geology, 39, 990-1000. https://doi.org/10.1007/ s002549900084

Matys Grygar, T., Elznicová, J., Bábek, O., Hošek, M., Engel, Z., \& Kiss, T. (2014). Obtaining isochrones from pollution signals in a fluvial sediment record: A case study in a uraniumpolluted floodplain of the Ploučnice River, Czech Republic. Applied Geochemistry, 48, 1-15. https://doi.org/ 10.1016/j.apgeochem.2014.06.021

Matys Grygar, T., \& Popelka, J. (2016). Revisiting geochemical methods of distinguishing natural concentrations and pollution by risk elements in fluvial sediments. Journal of Geochemical Exploration, 170(2016), 39-57. https://doi. org/10.1016/j.gexplo.2016.08.003

Meybeck, M., \& Helmer, R. (1989). The quality of rivers: from pristine stage to global pollution. Paleogeog. Paleoclimatol. Paleoecol, 75, 283-309. https://doi.org/10.1016/09218181(89)90007-6

Mlayah, A., Ferrera da Silva, E., Rocha, F., Ben Hamza, Ch., Charef, A., \& Noronha, F. (2009). The Oued Mellègue: Mining activity. Stream sediments and dispersion of base metals in natural environments North-western Tunisia. Journal of Geochemical Exploration, 102, 27-36. https:// doi.org/10.1016/j.gexplo.2008.11.016

Miller, J., Barr, R., Grow, D., Lechler, P., Richardson, D., Waltman, K., \& Warwick, J. (1999). Effects of the 1997 flood on the transport and storage of sediment and mercury within the Carson River valley, west-centr al Nevada. The Journal of Geology, 107, 313-327. https://doi.org/10.1086/ 314353

Moore, J. N., Brook, E. J., \& Johns, J. (1989). Grain size partitioning of metals in contaminated coarse-grained river floodplain sediment: Clark Fork River, Montana, USA. Environ Geol Water S, 14(2), 107-115. https://doi.org/10. 1007/BF01728502

Morillo, J., Usero, J., \& Gracia, I. (2002). Partitioning of metals in sediments from the Odiel River (Spain). Environment International, 28, 263-271. https://doi.org/10.1016/s01604120(02)00033-8

Müller, G. (1979). Index of geoaccumulation in sediments of the Rhine River. J Geo, 2, 109-118.

Nguyen, T. H., Hoang, H. N. T., Bien, N. Q., Tuyen, L. H., \& Kim, K. W. (2020). Contamination of heavy metals in paddy soil in the vicinity of Nui Phao multi-metal mine. Environ Geochem Health. https://doi.org/10.1007/s10653020-00611-5

Pascaud, G., Boussen, S., Soubrand, M., Joussein, E., Fondaneche, P., Abdeljaouad, S., \& Bril, H. (2015). Particulate transport and risk assessment of $\mathrm{Cd}, \mathrm{Pb}$ and $\mathrm{Zn}$ in a Wadi contaminated by runoff from mining wastes in a carbonated semi-arid context. Journal of Geochemical Exploration. https://doi.org/10.1016/j.gexplo.2015.01.009

Oyarzun, R., Lillo, J., López-García, J. A., Esbrí, J. M., Cubas, P., Llanos, W., \& Higueras, P. (2011). The Mazarrón Pb(Ag)-Zn mining district (SE Spain) as a source of heavy metal contamination in a semiarid realm: Geochemical data from mine wastes, soils, and stream sediments. Journal of Geochemical Exploration, 109, 113-124. https://doi. org/10.1016/j.gexplo.2010.04.009

Owens, P.N., Walling, D.E., He, Q., Shanahan, J., Foster, I.D.L., 1997. The use of caesium-137 measurements to establish a sediment budget for the Start catchment, Devon, UK. Hydrol Sci J 42, 405-423. DOI:https://doi.org/10.1080/ 02626669709492037

Reimann, C., \& Garrett, R. G. (2005). Geochemical background concept and reality. Science of the Total Environment, 350, 12-27. https://doi.org/10.1016/j.scitotenv.2005.01.047

Ribeiro, J., DaBoit, K., Flores, D., Ward, C. R., \& Silva, L. F. O. (2010). Identification of nanominerals and nanoparticles in burning coal waste piles from Portugal. Science of the Total Environment, 408, 6032-6041. https://doi.org/10.1016/j. scitotenv.2010.08.046

Rieuwerts, J. S., Thornton, I., Farago, M. E., \& Ashmore, M. R. (2015). Factors influencing metal bioavailability in soils: Preliminary investigations for the development of a critical loads approach for metals. Chemical Speciation and Bioavailability, 10, 61-75.

Rouvier, H. (1977). Géologie de l'Extrême Nord - tunisien: Tectonique et paléogéographies superposées à l'extrémité orientale de la chaîne nord-maghrébine (p. 703). Thèse d'Etat. 
Rouvier, H., Perthuisot, V., \& Mansouri, A. (1985). Pb-Zn deposits and salt-bearing diapirs in Southern Europe and North Africa. Economic Geology, 80, 666-687. https://doi. org/10.2113/gsecongeo.80.3.666

Sainfeld. P., 1952. Les gîtes plombo-zincifères de Tunisie. Annales des Mines et de la Géologie 9, Tunis, 285 pp.

Salminen, R., Tarvainen, T., Demetriades, A., Duris, M., Fordyce, F.M., Gregorauskiene, V., et al. 1998. FOREGS geochemical mapping field manual. Espoo: Guide 47, Geological Survey of Finland.

Salomons, W. (1995). Environmental impact of metals derived from mining activities: Processes, predictions, prevention. Journal of Geochemical Exploration, 52, 5-23. https://doi. org/10.1016/0375-6742(94)00039-E

Salvarredy-Aranguren, M. M., Probst, A., Roulet, M., \& Isaure, M. P. (2008). Contamination of surface waters by mining wastes in the Milluni Valley (Cordillera Real, Bolivia): Mineralogical and hydrological influences. Applied Geochemistry, 23, 1299-1324. https://doi.org/10.1016/j. apgeochem.2007.11.019

Sappa G., Barbieri M., Andrei F., Ferranti F. 2019 Assessment of arsenic mobility in a shallow aquifer from Bevera Valley Basin (Northern Italy). Arabian Journal of Geosciences Volume 12, Issue 22, 1 November 2019, Article number 678. https://doi.org/10.1007/s12517-019-4764-7

Sbarbati, C. Barbieri, M. Barron, A., Bostick, B. Colombani, N., Mastrocicco, M., Prommer, H., Passaretti, S., Zheng.ì, Y., Petitta, M. 2020. Redox dependent arsenic occurrence and partitioning in an industrial coastal aquifer: Evidence from high spatial resolution characterization of groundwater and sediments. Water (Switzerland) Open AccessVolume 12, Issue 10, October 2020, Article number 2932, Pages 1-20. DOI:https://doi.org/10.3390/w12102932

Slim-Shimi, N., \& Tlig, S. (1993). Mixed type sulfide deposits in Northern Tunisia. Regenerated in relation to paleogeography and tectonism. Journal of African Earth Sciences, 16, 287-307. https://doi.org/10.1016/08995362(93)90050-Z

Shruti, V. C., Jonathan, M. P., Rodríguez-Espinosa, P. F., Nagarajan, R., Escobedo-Urias, D. C., Morales-García, S. S., Souissi, R., Souissi, F., Chakroun, H. K., \& Bouchardon, J. L. (2013). Mineralogical and geochemical characterization of mine tailings and $\mathrm{Pb}$. $\mathrm{Zn}$. and Cd mobility in a carbonate setting (Northern Tunisia). Mine Water and the Environment, 32, 16-27. https://doi.org/10.1007/s10230012-0208-2

Smedley, P. L., \& Kinniburgh, D. G. (2002). A review of the source, behaviour and distribution of arsenic in natural waters. Applied Geochemistry, 17, 517-568. https://doi. org/10.1016/S0883-2927(02)00018-5

Souissi, R., Souissi, F., Chakroun, H. K., et al. (2013). Mineralogical and geochemical characterization of mine tailings and $\mathrm{Pb}, \mathrm{Zn}$, and $\mathrm{Cd}$ mobility in a carbonate setting (Northern Tunisia). Mine Water and the Environment, 32, 16-27. https://doi.org/10.1007/s10230-012-0208-2.

Taylor, M. P. T., \& Kesterton, R. G. H. (2002). Heavy metal contamination of an arid river environment: Gruben River, Namibia. Geomorphology, 42, 311-327. https://doi.org/10. 1016/S0169-555X(01)00093-9

Taylor, S. R., \& McLennan, S. M. (1985). The continental crust: Its composition and evolution. Blackwell.

Varol, M. (2011). Assessment of heavy metal contamination in sediments of the Tigris River (Turkey) using pollution indices and multivariate statistical techniques. Journal of Hazardous Materials, 195, 355-364. https://doi.org/10. 1016/j.jhazmat.2011.08.051

Violante, A., Cozzolino, V., Perelomov, L., Caporale, A. G., \& Pigna, M. (2010). Mobility and bioavailability of heavy metals and metalloids in soil environments. Journal of Soil Science and Plant Nutrition, 10(3), 268-292. https://doi. org/10.4067/S0718-95162010000100005

Wang, J., Liu, R., Wang, H., Yu, W., Xu, F., \& Shen, Z. (2014). Identification and apportionment of hazardous elements in the sediments in the Yangtze River estuary. Environmental Science and Pollution Research, 22, 20215-20225.

Wang, J., Liu, G., Lu, L., Zhang, J., \& Liu, H. (2015). Geochemical normalization and assessment of heavy metals $(\mathrm{Cu}, \mathrm{Pb}, \mathrm{Zn}$, and $\mathrm{Ni})$ in sediments from the Huaihe River, Anhui, China. CATENA, 129, 30-38.

Wedepohl, H. (1995). The composition of the continental crust. Geochimica et Cosmochimica Acta, 59, 1217-1232.

Wolfenden, P. J., \& Lewin, J. (1977). Distribution of metal pollutants in floodplain sediments. CATENA, 4, 309-317.

Yacoub, C., \& Pérez-Foguet., A., Valderrama. C., Miralles, N., . (2014). Impacts on effluent contaminants from mine sites: risk assessment, fate, and distribution of pollution at basin scale. Environmental Science and Pollution Research. https://doi.org/10.1007/s11356-014-2559-7

Zuluaga, M. C., Norini, G., Lima, A., Albanese, S., David, P., \& De Vivo, B. (2016). Stream sediment geochemical mapping of the Mount Pinatubo-Dizon Mine area, the Philippines: Implications for mineral exploration and environmental risk. Journal of Geochemical Exploration. https://doi.org/10.1016/j.gexplo.2016.12.012

Zuzolo, D., Cicchella, D., Catani, V., Giaccio, L., Guagliardi, I., Esposito, L., \& De Vivo, B. (2016). Assessment of potentially harmful elements pollution in the Calore River basin (Southern Italy). Environmental Geochemistry and Health. https://doi.org/10.1007/s10653-016-9832-2

Publisher's Note Springer Nature remains neutral with regard to jurisdictional claims in published maps and institutional affiliations. 